\title{
Meaningful Experience Of Motivation To Power Seller With Orientation On Consumer Satisfaction For Identification Of Employee Benefits In The Textile Sales In South Surabaya
}

\author{
Etin Puspitasari ${ }^{1}$, Wulandari Harjanti ${ }^{2}$ \\ ${ }^{1}$ HighSchool of Economics Mahardhika \\ ${ }^{2}$ High School of Economics Mahardhika \\ dra.wulandariong@gmail.com
}

\begin{abstract}
Purpose : How to influence meaningful experiences to motivate salespeople with an orientation on the identification Consumer satisfaction with the reward at the sales employee Textile in South Surabaya.

Design/methodology/approach : The research approach used in this study is a quantitative approach, the research focuses on hypothesis testing. The data used is the data measured and will produce results that can be generalized. This study is causal because it will examine the influence between variables.

Findings Based on the results of the regression analysis shows that the significance value (Sig) $t$ is 0.025 . Because the value (Sig) $0.025 t$ less than the level $\square 5 \%(0.05)$, the satisfaction of reward (pay satisfaction) strengthening the influence of a meaningful experience (experienced meaningfulness) to motivate salespeople to make customer orientation significantly.

Research limitations/implications : This study uses the sales advisor respondents. General job description of this section is to conduct the sale of textile unit according to the targets set, which includes the search for Consumers (prospecting), Negotiation, closing, administrative process of sales, delivery and complaint.

Practical implications : A validity test is used to determine the extent of measuring instruments used actually measure what yang want to be measured. The test is performed using Pearson Product Moment Correlation.

Originality/value : The results showed meaningful experience (experienced meaningfulness) significantly affect the motivation of salespeople to make customer orientation and satisfaction with rewards (pay satisfaction) strengthening the influence of meaningful experience (experienced meaningfulness) to motivate salespeople to make customer orientation significantly.
\end{abstract}

Paper type : Research paper

Keyword : Sales, Motivation, Rewards, Customer

Meaningful Experience Of Motivation To Power Seller With Orientation On Consumer Satisfaction For Identification Of Employee Benefits In The Textile Sales In South Surabaya

Etin Puspita sari, Wulandari Harjanti 


\section{INTRODUCTION}

Focus on the consumer puts consumers at the highest priority. When companies put consumers at the heart of its business, put consumers as part of the organizational culture, then the company can be said to be the company that focuses on the consumer (customer centric). Field of consumer-oriented management is termed a customer relationship management (CRM).

CRM related full consumer cycle. When companies implement CRM strategy, the company will explore and analyze data abo ut the target consumer and purchasing behavior. Based on this information, companies can understand and predict consumer behavior. Marketing efforts is equipped with customer intelligence will be able to find new customers and explore more and more of the consumer wallet now.

Approaching the consumer, the salesperson is an important spearhead for the company. The main point of the function of the salesperson is to help consumers make purchasing decisions that will satisfy consumer preferences. There are two sales strategy used in this case, namely the sale of consumer oriented (customer orientation) and oriented only on sales (sales orientation). Both orientations are different according to the objective and the means used to achieve the goal. According to Saxe and Weitz (1982), "consumer-oriented sales (customer-oriented selling) creates long-term benefits are better salesperson than the salesperson oriented sales (sales-oriented selling)". Saxe and Weitz (1982) says that,

According to Saxe and Weitz (1982), said that "high-oriented salespeople at the expense of consumers avoid actions that consumer interests, in order to increase the likelihood of quick sales." The purpose of the orientation of the sale is to satisfy consumer preferences are clearly visible. The orientation of the consumer insists on listening to consumers and dialogue activities, while the orientation of the intent opportunistic sales support required to generate sales.

Meaningful Experience Of Motivation To Power Seller With Orientation On Consumer Satisfaction For Identification Of Employee Benefits In The Textile Sales In South Surabaya Etin Puspita sari, Wulandari Harjanti 
Model job characteristics (Job Characteristics Model) Of Hackman and Oldham (1980), as cited by Lawrence (2001), says that "the motivation to work is a function of three conditions main psychological, ie meaningful experience on the job (experienced meaningfulness), the experience of responsibility (experienced responsibility) the output job, and knowledge of the actual results of work activity. "Lawrence (2001) revealed that" Three major psychological condition is determined by five job characteristics, namely the diversity of expertise, task identity, task significance, autonomy, and feedback. "

Another factor that also determines the orientation of the motivation of consumers on the salesperson is the satisfaction of reward. One of the largest components of the compensation is salary, because it is often confused with a salary compensation. According Nitisemito (1996: 197), "salary itself is also the fringe benefits provided by the company / institution to employees / employee who can be valued in money and has a tendency to be given a permanent basis."

Compensation issues related to the internal consistency and external consistency. Internal consistency relates to the concept of relative payroll in the organization, while the external consistency with regard to the relative levels prevailing salary structure within the organization as compared to the applicable payroll outside the organization. According to Gomes (1995: 129), "The balance between internal and external consistency are important to note in order to ensure a sense of satisfaction, and workers stay motivated, as well as the effectiveness of the organization as a whole."

According to Walker (1977), in Thakor and Joshi (2005), "satisfaction with rewards refer evaluations positive assessment of reward received in exchange for the efforts that have been made by a salesperson." The higher the reward received, the higher power capability sellers to achieve the goal. 


\section{Formulation Of The Problem}

Based on the background described previously, the problems will be examined in this study is ssa follows: How to influence meaningful experiences to motivate salespeople with an orientation on the identification Consumer satisfaction with the reward at the sales employee Textile in South Surabaya?.

\section{MATERIAL AND METHOD}

The research approach used in this study is a quantitative approach, the research focuses on hypothesis testing. The data used is the data measured and will produce results that can be generalized. This study is causal because it will examine the influence between variables.

The variables used in this study are detailed as follows: free or independent variable (X), a meaningful experience (experienced meaningfulness) (X1), Satisfaction with compensation (Pay Satisfaction) (X2). And bound or dependent variable $(Y)$, consumer-oriented sales motivation (Customer-oriented selling motivation)

\section{Data Collection Procedures}

Data required in this study were collected through field surveys, interviews or questionnaires, and literature study as a complementary method for collecting secondary data. The methods used are detailed as follows: Field surveys or research, interviews and questionnaires, Study of literature

The research subjects who will be the respondent for data collection was 41 salespeople Textile South Surabaya.

Analysis model used in this research is multiple linear regression model (multiple linear regression) Interaction. Interactions between independent variables occurs when the effect of an independent variable on the variable is 
not constant at all values of the independent variables (Allen, 1997: 118). An interaction variable is the variable that is the result of the multiplication of two or more independent variables. (Allen, 1997: 119). The level of interaction variables influence directly related to the degree of influence of the two independent variables that are used to shape it. If the observations showed a high value on both the independent variable, then the value of the variable interactions will also be high (Allen, 1997: 119).

\section{Mechanical Analysis}

The analysis is done by using multiple regression quantitative methods, are used to test hypotheses with the test criteria t test at significance level of $5 \%$.

\section{RESULTS AND DISCUSSION}

This study uses the sales advisor respondents. General job description of this section is to conduct the sale of textile unit according to the targets set, which includes the search for Consumers (prospecting), Negotiation, closing, administrative process of sales, delivery and complaint. The description in full is as follows:

\section{Characteristics Of Respondents}

Classification of groups of respondents according to age levels, where respondents aged less than 25 years as much as 2 or $5 \%$, of respondents aged 25-30 years as many as 10 people or 24\%, of respondents aged 31-35 years as many as 13 people or 32\%, of respondents aged 36-40 years as many as 11 people or $27 \%$, and respondents over the age of 40 years as many as 5 people or $12 \%$..

Classification of respondents by sex shows that all respondents are

Meaningful Experience Of Motivation To Power Seller With Orientation On Consumer Satisfaction For Identification Of Employee Benefits In The Textile Sales In South Surabaya Etin Puspita sari, Wulandari Harjanti 
respondents with male gender, ie 41 or $100 \%$.

Classification groups of respondents according to the last study, where respondents with high school education level end as much as 3 or $7 \%$, of respondents with education level of the end of the Diploma as many as 9 people or $22 \%$, and respondents with the end of undergraduate education as much as 29 or $71 \%$.

Classification of the working groups of respondents according to age, where respondents with tenure of less than one year as many as 6 people or $15 \%$, of respondents with tenure of 12 years as many as 9 people or $22 \%$, of respondents with terms of 2-4 years as many as 12 people or $29 \%$ of respondents with terms of 4-5 years as many as 11 people or $27 \%$, and respondents with tenure of more than five years as many as 3 people or $7 \%$.

\section{Category Rate of Each Variable Research}

To perform the rating assessment categories for each variable, it is necessary for the interval scale division five levels of assessment with the following formula:

$$
\frac{5-1}{5}=0,8
$$

The results of the ranking of the five scale interval can then be compared with the average value of each study variable, so it can be a category assessment. Based on the calculation above it can be arranged scale of assessment categories for each variable as follows: for a variable $X 1$ (meaningful experience) the average value is equal to 4.22 , meaning that the overall average employee considers that his current work is very meaningful. For X2 (the satisfaction of reward) is the average value of 4.21 , meaning that the overall average employees are delighted with the rewards that diterima.Dan variable $Y$ (consumer-oriented sales motivation) the average value is equal to

Meaningful Experience Of Motivation To Power Seller With Orientation On Consumer Satisfaction For Identification Of Employee Benefits In The Textile Sales In South Surabaya Etin Puspita sari, Wulandari Harjanti 
4.16 ,

\section{Validity and Reliability Testing}

A validity test is used to determine the extent of measuring instruments used actually measure what want to be measured. The test is performed using Pearson Product Moment Correlation. The correlation coefficient of each item statement than the critical value of $r$ in the table Pearson Product Moment, in accordance with the degrees of freedom and level of significance. When the correlation coefficient is greater than the critical value then a statement is considered valid, otherwise if the correlation coefficient is smaller than the critical value then a statement is considered void.

Respondents amounted to 41 people, with a significance level of $5 \%$ and the value of $d f(\mathrm{~N}-2)=39$, then the critical value of correlation Pearson is 0.325 . Results of testing the validity of the grains statements for all independent variables, are all valid because the value of $r$ count of each item statement greater than the critical $r$ value of 0.325 .

\section{Testing Reliability}

Reliability is an index indicating the degree to which a measuring instrument can be trusted or relied upon, in other words, the reliability showed consistency measuring instrument in measuring the same symptoms. The reliability testing using coefficient method Cronbach Alpha, The test results have Cronbach alpha values above 0.6 , so it can be concluded that the device used to measure the expression of each variable can be relied upon.

\section{Model Analysis and Hypothesis Testing}

The analysis technique used in this research is regression moderation, with sales of consumer-oriented motivation as dependent variable $(Y)$ and the independent variables The Meaningful Experiences $\left(X_{1}\right)$, And the

\footnotetext{
Meaningful Experience Of Motivation To Power Seller With Orientation On Consumer Satisfaction For Identification Of Employee Benefits In The Textile Sales In South Surabaya Etin Puspita sari, Wulandari Harjanti
} 
satisfaction of reward (X2). To perform regression analysis moderation, $X$ variable data must first be centered transformed data, by reducing the average data each respondent's answer with the overall average (mean) of each variabel.Setelah the data is transformed, the next process is to run a simple regression for influence experience significant variable $(X 1)$ to consumeroriented sales motivation $(Y)$. The regression analysis of $Y=4.157+1,152 X 1$

The regression analysis shows that the constant has a value of 4.157, which is the intersection of the regression line with the $\mathrm{Y}$-axis shows the level of sales of consumer-oriented motivation when variables meaningful experience $\left(X_{1}\right)$ Has a value of 0 . Variable meaningful experience $(X 1)$ having a positive regression coefficient, meaning that if the variable meaningful experience (X1) increased by one unit then the consumer-oriented sales motivation $(\mathrm{Y})$ increased by the value of the regression coefficient is equal to 1.152 , assuming other independent variables remain.

The regression analysis also showed that the contribution of the variables meaningful experience (X1) on the dependent variable, consumeroriented sales motivation $(\mathrm{Y})$, which is indicated by the coefficient of multiple determination (R2) is approximately 0.639 . This means that $63.9 \%$ of consumer-oriented sales motivation level is determined by changes in experience significant variable (X1). The remaining portion of $36.1 \%$ of consumer-oriented sales motivation level is determined by other variables not examined.

Multiple correlation coefficient values or multiple regresion $(\mathrm{R})$ based on the results of the analysis are as big as 0,800 . This coefficient shows the degree of relationship (correlation) between the variables meaningful experience $(\mathrm{X} 1)$ with the dependent variable $(\mathrm{Y})$,consumer-oriented sales motivation. High $R$ value, which amounted to 0,800 , indicating a strong relationship between the variables $(\mathrm{X} 1)$, with the depe ndent variable $(\mathrm{Y})$. 
The results of the analysis of $t$ test with significance level of $5 \%$ explained that experience significant variable $(X 1)$ has a significant effect on the consumer-oriented sales motivation variable $(Y)$, with the level of error probability of 0.000 smaller than the significance level of 0.05 .

After a meaningful experience variable (X1) proved a significant effect on the consumer-oriented sales motivation $(\mathrm{Y})$, then developed a second regression analysis model was developed to prove theoretically influence a meaningful experience variable $(X 1)$ and satisfaction with compensation (X2). The results of the second model regression analysis $Y=4.155+0,608 X 1+$ $0,372 \times 3$

The multiple linear regression model to explain things as follows:

1. The constant of 4.155 is the intersection of the regression line with the $\mathrm{Y}$-axis shows the level of sales of consumer-oriented motivation when all independent variables, namely a meaningful experience (X1), and the satisfaction of reward (X3), equal to 0 .

2. Variable meaningful experience $(X 1)$ has a regression coefficient is positive, meaning that if the variable meaningful experience (X1) increased by one unit then motivated sales of consumer-oriented $(Y)$ increased by the value of regression coefficient that is equal to 0.608 , assuming other independent variables remain.

3. Variable satisfaction of reward (X2) having a positive regression coefficient, meaning that if the variable satisfaction with compensation (X2) increased by one unit then the consumer-oriented sales motivation ( $Y$ ) increased by the value of the regression coefficient is 0.372 , assuming other variables remain.

The regression analysis also showed that the contribution of independent variables, meaningful experience $\left(X_{1}\right)$ And the satisfaction of reward $(X 2)$, the dependent variable, customer-oriented sales motivation $(Y)$, which is indicated 
by the coefficient of multiple determination (R2) is approximately 0.766 . This means that $76.6 \%$ of consumer-oriented sales motivation level is determined by changes all independent variables included in the regression model. Thus the remaining $23.4 \%$, consumer-oriented sales motivation is determined by other variables not examined.

Multiple correlation coefficient values or multiple regresion $(R)$ based on the results of the analysis is 0.875 . This coefficient shows the degree of relationship (correlation) between the independent variables, meaningful experience $(X 1)$ and the satisfaction of reward (X2), with the dependent variable $(Y)$, consumer-oriented sales motivation. High $R$ value, which is 0.875 , indicating a strong relationship between all independent variables, namely a meaningful experience (X1) and the satisfaction of reward (X2), with the dependent variable,consumer-oriented sales motivation $(\mathrm{Y})$.

The results of the analysis of $t$ test with significance level of $5 \%$ explained things as follows:

1. Experience significant variables (X1) has a significant effect on the consumer-oriented sales motivation variable $(\mathrm{Y})$, with the value of the error probability of 0.001 smaller than the significance level of 0.05 .

2. Variable satisfaction of reward (X2) have a significant effect on the consumer-oriented sales motivation variable $(\mathrm{Y})$, because it has an error probability value of 0.005 which is smaller than the significance level of 0.05 .

Having proven that all independent variables have a significant influence the subsequent regression analysis is to enter moderating variables, namely the interaction between a meaningful experience with the satisfaction of reward (X1X2). Results analysis moderation regression analysis equation linear regression models as follows:

$$
\mathrm{Y}=4.068+0,573 \times 1+0,410 \times 20,635 \times 1 \times 2
$$


Volume 1 Number 12017

This work is licensed under a Creative Commons Attribution-

ShareAlike 4.0 International License.

The multiple linear regression model to explain things as follows:

1. The constant of 4.068 is the intersection of the regression line with the Y-axis shows sales motivation consumer oriented when all independent variables, namely meaningful experience (X1), satisfaction with rewards (X2), the interaction on meaningful experience and satisfaction with the rewards (X1X2) equals 0.

2. Variable meaningful experience $(X 1)$ has a regression coefficient is positive, meaning that if the variable meaningful experience (X1) increased by one unit then motivated sales of consumer-oriented $(Y)$ increased by the value of regression coefficient that is equal to 0.573 , assuming other independent variables remain.

3. Variable satisfaction of reward (X2) having a positive regression coefficient, meaning that if the variable satisfaction with compensation (X3) increased by one unit then the consumer-oriented sales motivation $(Y)$ increased by the value of the regression coefficient is 0.410 , assuming other variables remain.

4. Variable interaction between meaningful experience and satisfaction with the rewards $(\mathrm{X} 1 \mathrm{X} 2)$ had a regression coefficient is positive, meaning that if the variable interactions between meaningful experience and satisfaction with the rewards (X1X2) increased by one unit then motivated sales of consumer-oriented $(Y)$ increased by coefficient regression that is equal to 0.635 , assuming other variables remain.

The regression analysis also showed that the contribution of independent variables, meaningful experience $\left(X_{1}\right)$ And the satisfaction of reward $(X 2)$ and the interaction between meaningful experience with the satisfaction of reward (X1X3) on the dependent variable, orientation consumer-oriented sales motivation $(\mathrm{Y})$, which is indicated by the coefficient of multiple determination 
(R2) is approximately 0.834 . This means that $83.4 \%$ of consumer-oriented sales motivation level is determined by changes all independent variables included in the regression model. Thus the remaining $16.6 \%$, consumer-oriented sales motivation is determined by other variables not examined.

Multiple correlation coefficient values or multiple regresion $(R)$ based on the results of the analysis amounted to 0.913 . This coefficient shows the degree of relationship (correlation) between the independent variables, meaningful experience (X1) and the satisfaction of reward (X2), and the interaction between meaningful experience with the satisfaction of reward (X1X2), with the dependent variable $(Y)$,consumer-oriented sales motivation. Rated $R$ high, amounting to 0.913 , indicating a strong relationship between all independent variables, namely meaningful experience (X1), and the satisfaction of reward (X2), and the interaction between meaningful experience with the satisfaction of reward $(\mathrm{X} 1 \mathrm{X} 3$ ) with variable bound, consumer-oriented sales motivation $(\mathrm{Y})$.

Based on the analysis it appears that the value of the coefficient of multiple determination $\left(R^{2}\right)$ After entering the moderating variable is equal to 0.834 , which is higher than the value of the coefficient of multiple determination (R2) before the variable moderation, that is equal to 0.766 . This means that the moderating variable affecting the motivation is proven to be more consumeroriented sales. This is consistent with what is said by Hair et. al. (1998: 147), that the regression model with moderating variables proved to be more influential if the value of the coefficient of multiple determination (R2) in regression models with variable moderation higher value than the regression model without the moderating variable.

To determine the effect of moderator should set specific values used to describe the moderating effect of regression models were analyzed. Interaction between meaningful experience and satisfaction with the rewards (X1X3), indicating that regression sales motivation consumer oriented $(\mathrm{Y})$ on a 
Volume 1 Number 12017

This work is licensed under a Creative Commons Attribution-

ShareAlike 4.0 International License.

meaningful experience (X1) depends on the specific value of the identification of the satisfaction of reward (X2), to generate slope meaningful experience ( X1) on the satisfaction of reward (X2).

In this study, the variables that are hypothesized as a moderator variable is the satisfaction of reward $\left(\mathrm{X}_{2}\right)$. Thus, the regression model equation can be transformed as follows:

$\mathrm{Y}=4.068+0,573 \mathrm{X} 1+0,410 \mathrm{X} 2+0,635 \mathrm{X} 1 \mathrm{X} 2$

Results of descriptive statistical analysis on the data centered each independent variable shows the mean and standard deviation. If the satisfaction of reward (X2) as a moderator variable, then the calculation is done to determine the value of the conditional factor (moderator variables) are as follows:

$$
\begin{aligned}
& \text { Mean }=0 \text { and standard deviation }=0.38 \\
& \mathrm{X} 2 \mathrm{H}=+0.38 \\
& \mathrm{X} 2 \mathrm{M}=0 \\
& \mathrm{X} 2 \mathrm{~L}=-0.38
\end{aligned}
$$

When the satisfaction of reward (X2) as a moderator variable, the equation used is as follows:

$$
\mathrm{Y}=(0.573+0,635 \mathrm{X} 2) \mathrm{X} 1+(0,410 \mathrm{X} 2+4.068)
$$

When:

$$
\begin{aligned}
& \mathrm{X} 2 \mathrm{~L}=-0.38 \text {, then } \mathrm{Y}=3.91+0,33 \mathrm{X} \\
& \mathrm{X} 2 \mathrm{M}=0 \text {, Makay }=4.068+0,573 \mathrm{X} \\
& \mathrm{X} 2 \mathrm{H}=+0.38 \text {, Makay }=4.22+0,81 \mathrm{X} \\
& \text { The resulting equation moderation } \\
& \text { rewards }\left(\mathrm{X}_{2}\right) \text { As a moderator variable is: } \\
& \text { 1. If } \mathrm{X} 2 \mathrm{~L}=-0.38 \text {, then } \mathrm{Y}=3.91+0,33 \mathrm{X} 1 \\
& \text { 2. If } \mathrm{X} 2 \mathrm{M}=0, \mathrm{Y}=4.068+0,573 \mathrm{X} 1 \\
& \text { 3. If } \mathrm{X} 2 \mathrm{H}=+0.38 \text {, then } \mathrm{Y}=4.22+0,81 \mathrm{X} 1
\end{aligned}
$$

The resulting equation moderation when variables satisfaction with 
If the condition X2M, showing similarities upon satisfaction of reward is at the average level, when conditions $\mathrm{X} 2 \mathrm{~L}$ and $\mathrm{X} 2 \mathrm{H}$ indicate when the satisfaction of low and high rewards. Because of the attention is focused on the growing influence of meaningful experience $(X 1)$ to sales motivation consumer oriented (Y) upon the occurrence of the satisfaction of reward (X2) is high, then the analysis of the strong influence of the moderation seen in the change in the regression coefficient meaningful experience $(X 1)$, so that the effect of moderating effects are as follows:

1. Positive moderating effect $=(0.81$ to 0.573$) / 0.573=41.36 \%$

2. Negative moderating effects $=($ from 0.33 to 0.573$) / 0.573=42.4 \%$

A positive moderating effect is called the effect of amplification or amplifying effect, whereas a negative moderating effect, simply called the moderating effects.

\section{Deviation Test Regression Model}

In the aberration test VIF overall regression independent variables VIF is less than the critical value of 10 , so it can be concluded that the model does not happen multikolinearitas symptoms.

Heteroskidastity mean variation (variance) is not the same variable for all observations. In heteroskedastities, errors that occur are not random (random), but shows the systematic relationship in accordance with the amount of one or more independent variables. So based on Heteroskidastity test showed that all independent variables have no significant relationship with confounding variables, where the value of the significance of Spearman Rank correlation coefficient for all the independent variables were still above the significant level value $(\square) 5 \%$. 


\section{Hypothesis testing}

Meaningful experience (experienced meaningfulness) affect motivation for salespeople to consumer orientation, can be seen the value of the variable $t$ significance meaningful experience. If the results of the t statistic at significant level $\square=5 \%$ significance value (sig) is less than 0.05 , meaning variables meaningful experiences have a significant impact on the motivation variable salesperson to consumer orientation.

Based on the results of the regression analysis shows that the significance value (Sig) is 0,001 $\mathrm{t}$. Because the value (Sig) $t$ is 0,001 less than the level $5 \%(0.05)$, the significant experience (experienced meaningfulness) significantly affects the motivation of salespeople to consumer orientation.

For testing satisfaction with rewards (Pay satisfaction) strengthening the influence of a meaningful experience (experienced meaningfulness) to motivate salespeople to consumer orientation, can be seen the value of the variable $t$ significance meaningful interaction between experience with satisfaction on benefits. If the results of the $t$ statistic at significant level $\square=5 \%$ significance value (sig) is less than 0.05 , it means that the variable interactions between meaningful experience with satisfaction on benefits have a significant impact on the motivation variable salesperson to consumer orientation.

Based on the results of the regression analysis shows that the significance value (Sig) $t$ is 0.025 . Because the value (Sig) $0.025 \mathrm{t}$ less than the level $\square 5 \%$ (0.05), the satisfaction of reward (pay satisfaction) strengthening the influence of a meaningful experience (experienced meaningfulness) to motivate salespeople to make customer orientation significantly.

\section{RESULT AND DISCUSSION}

The results showed that the interaction between experience a meaningful and significant impact on organizational identification salesperson motivation to 
consumer orientation, and interaction between meaningful experience with satisfaction on benefits also significant effect on the motivation of the salesperson to consumer orientation. Both the results of these studies indicate that despite significant experience greatly affect salesperson motivation to do the orientation on the consumer, but the effect will be increased again when salespeople also have a high organizational identification and satisfaction high on the rewards.

The regression analysis examined only the first phase of a significant effect on the motivation of the experience the salesperson to conduct orientation on consumers, proving that a meaningful experience indeed proved to have a significant effect on the motivation of salespeople to do the orientation on consumers. Employees who have significant experience will feel that the work being done at this time give him a chance to become a truly appreciated. Employees also feel that their work gives a feeling of success. Meaningful experience that is felt by employees will give rise to the idea that his work provides an opportunity to use their expertise in the field owned by employees. By working employees felt that he could give a better life. Employment is considered as an interesting and challenging, and provides an opportunity to grow and develop to obtain a better work experience. Employees gain meaningful experience if it can serve customers well, so feel satisfaction. This satisfaction will encourage employees to do a good job and do a better approach to the consumer taking into account the wishes. At the Textile, the results showed that the salesperson is in the average enterprise experience significantly high, which is indicated by the average of 4.22 employees meaningful experiences into the category of very meaningful according to the assessment scale. This shows that the employees really appreciate the job now. Employees consider that work in Textile is a success for him, because it has worked in large companies and provides the opportunity for employees to 
be appreciated by others.

Satisfaction with this high reward Textile encourages employees to work well in the interests of the company by way of sale to the consumer-oriented approach in order to provide long-term benefits for the company. This is consistent with that disclosed by Walker (1977), in Thakor and Joshi (2005), that the satisfaction of reward evaluation referencing the positive assessment of reward received in exchange for the efforts that have been made by the salesperson. The higher the reward is received, the higher the salesperson's ability to achieve goals. Therefore, the satisfaction of rewards will motivate the efforts carried out by triggering salespeople salesperson to pursue the expected value is obtained (Chebat, Babin, and Kolias, 2002). Then, satisfaction positively on benefits will affect salesperson motivation in an effort to make consumer orientation. If the high satisfaction for benefits interact with the high value meaningful experience (experienced meaningfulness), then the salesperson's motivation to engage in consumer orientation will increase, because employees receiving extrinsic and intrinsic rewards in exchange for the efforts that have been made. Thus, when the high-reward satisfaction, positive relationship between meaningful experience (experienced meaningfulness) motivated salespeople to increase efforts required for consumer orientation will also be growing (Chebat, Babin, and Kolias, 2002). If the high satisfaction for benefits interact with the high value meaningful experience (experienced meaningfulness), then the salesperson's motivation to engage in consumer orientation will increase, because employees receiving extrinsic and intrinsic rewards in exchange for the efforts that have been made. Thus, when the highreward satisfaction, positive relationship between meaningful experience (experienced meaningfulness) motivated salespeople to increase efforts required for consumer orientation will also be growing (Chebat, Babin, and Kolias, 2002). If the high satisfaction for benefits interact with the high value 
meaningful experience (experienced meaningfulness), then the salesperson's motivation to engage in consumer orientation will increase, because employees receiving extrinsic and intrinsic rewards in exchange for the efforts that have been made. Thus, when the high-reward satisfaction, positive relationship between meaningful experience (experienced meaningfulness) motivated salespeople to increase efforts required for consumer orientation will also be growing (Chebat, Babin, and Kolias, 2002). because employees receiving extrinsic and intrinsic rewards in exchange for the efforts that have been made. Thus, when the high-reward satisfaction, positive relationship between meaningful experience (experienced meaningfulness) motivated salespeople to increase efforts required for consumer orientation will also be growing (Chebat, Babin, and Kolias, 2002). because employees receiving extrinsic and intrinsic rewards in exchange for the efforts that have been made. Thus, when the highreward satisfaction, positive relationship between meaningful experience (experienced meaningfulness) motivated salespeople to increase efforts required for consumer orientation will also be growing (Chebat, Babin, and Kolias, 2002).

Other findings from the research shows that satisfaction amplification effect on benefits in a meaningful experience in motivating salespeople to conduct orientation on consumers is more powerful than the amplification effect on the organizational identification meaningful experience in motivating salespeople to conduct orientation on consumers. This shows that when employees feel meaningful experience on the job and supported its satisfaction with the rewards, then the employees will be more motivated to approach the consumer better, than when employees feel a meaningful experience with the identification of a strong organization. 


\section{CONCLUSION}

The results showed meaningful experience (experienced meaningfulness) significantly affect the motivation of salespeople to make customer orientation and satisfaction with rewards (pay satisfaction) strengthening the influence of meaningful experience (experienced meaningfulness) to motivate salespeople to make customer orientation significantly.

\section{REFERENCES}

Allen, M. P. (1997). Understanding Regression Analysis. Plenum Press, New York.

Anderson, K. and Kerr. C. (2002) Customer Relationship Management. McGraw-Hill Companies, Inc.

Armstrong, M. and Murlis, H. (1995) Pedoman Praktis Sistem Penggajian, Terjemahan, Cetakan Ketiga, Pustaka Binaman Pressindo, Jakarta.

Ashforth, B. E, and Mael, F. (1992) Alumni and Their Almamater: A Partial Test Of The Reformulated Model Of Organizational Identification. Journal of Organizational Behavavior. 13.

Bateman, T. S. and Crant, J. M. (1993) The proactive component of organizational behavior: A measure and correlates. Journal of Organizational Behavior, Vol. 14, No. 2.

Biberman, J., and Whitty, M. (1997) A Post-Modern Spiritual Future for Work. Journal of Organization Change Management, 10.

Brown, T. J., Mowen, J. C., Donavan, D. T., Licata, J. W. (2002) The Customer Orientation of Service Workers: Personality Trait Effects on Self- and Supervisor Performance Ratings. Journal of Marketing Research, Vol. 39, No. 1. 
Chebat, J. C., Babin, B., and Kolias, K. (2002) What Makes Contract Emlployee Perform? Reactions to Employee Pereceptions of Managerial Practices. International Journal of Bank Marketing. 20 (7).

Cohen, J. and Cohen, P. (1983) Applied Multiple Regression/Correlation Analysis for the Behavioral Sciences. Lawrence Erlbaum Associates: Hillsdale, New Jersey.

Flippo, E. B., (1994) Principles of Personnel Management, Sixth edition, McGraw-Hill Book Company, Tokyo.

Frankl, V. (1992) Man's search for meaning: An introduction to logotherapy. Boston: Beacon.

Gomes, F. C., (1995) Manajemen Sumber Daya Manusia, Cetakan Pertama, Andi Offset, Yogyakarta.

Grönroos, C. (1999) Relationship Marketing: Challenges for the Organization. Journal of Business Research, 46.

Handoko, T. Hani, (1994) Manajemen Personalia dan Sumber Daya Manusia, BPFE-UGM, Yogyakarta.

Hair, J. F., Anderson, R. E., Tatham, R. L., and Black, W. C. (1998) Multivariate Data Analysis. Fifth Edition. Prentice-Hall, Inc. New Jersey.

Heer, J., de Groenland, E.A.G. and Schoormand, J.P.L. (2002) How to obtain consumer requirements for the initial conseptualization of new products: Toward a context-aware consumer latent needs methodology. Corporate Report Series, TVRS/2002/153, Telematica Instituut: Enschede, The Netherlands.

Heidjrachman Ranupandojo, dan Suad Husnan, (1995) Manajemen Personalia, Edisi Keempat, Penerbit Fakultas Ekonomi Gadjah Mada, Yogyakarta. Holt, K. G., Horst P., Giovanni A. (1984). Need Assessment. A Key to UserOriented Product Innovation. John Wiley \& Sons: Chichester. Hughes, A.M. (2003) The Customer Loyalty Solution: What Works (and What 
Doesnt) in Customer Loyalty Programs. McGraw-Hill United States.

Lawrence, Robert. (2001) The Application of Hackman and Oldham's Job Characteristic Model to Perceptions Community Music School Faculty Have Towards Their Job. Academy of Management Journal, 21.

May, D. R., Gilson, R. L., and Harter, L. M. (2004) The Psychological Conditions of Meaningfulness, Safety and Availability and The Engagement of The Human Spint at Work. Journal of Occupational and Organizational Psychology. 77.

Nitisemito, Alex S., (1996) Manajemen Personalia (Manajemen Sumber Daya Manusia), Cetakan 9, Edisi Ketiga, Ghalia Indonesia, Jakarta.

Pascarella, P. (1998) Rethinking The Pursuit of Happiness. Management Review, 87.

Saxe R, and Weitz BA. (1982) The SOCO Scale: A Measure Of The Customer Orientation Of Salespeople. Journal of Marketing Research. 19(August).

Simamora, Henry, (1995) Manajemen Sumber Daya Manusia, Cetakan

Pertama, Penerbit Bagian Penerbitan STIE YKPN, Yogyakarta.

Spreitzer, G. M., Kizilos, M. A., \& Nason, S. W. (1997) A dimensional analysis of the relationship between psychological empowerment and effectiveness, satisfaction, and strain. Journal of Management, 23.

Thakor, M.V., and Joshi, A.W. (2005) Motivating Salesperson Customer Orientation: Insights from The Job Characteristics Model. Journal of Business Research. 58.

Tropp, L.R., \& Wright, S.C. (2001) In group identification as the inclusion of ingroup in self. Personality and Social Psychology Bulletin, 27.

Van Dyne, L., Jill, W. G. and Richard M. D. (1994), Organizational Citizenship Behavior: Construct Redefinition, Measurement, and Validation, Academy of Management Journal, 37 (August).

Whetten, D. A. and P. Godfrey, Eds. (1998). Identity in organizations: Building

Meaningful Experience Of Motivation To Power Seller With Orientation On Consumer Satisfaction For Identification Of Employee Benefits In The Textile Sales In South Surabaya Etin Puspita sari, Wulandari Harjanti 
International Journal of Entrepreneurship and Business Development

Volume 1 Number 12017

This work is licensed under a Creative Commons Attribution-

ShareAlike 4.0 International License.

theory through conversations. Thousand Oaks, CA, Sage.

Williams, L. J. (1988) Affective and Non affective Components of Job Satisfaction and Organizational Commitment as Determinants of Organizational Citizenship and in-role Behaviors. Jurnal of Organizational Behavior. 29. 